\title{
The Enzymes of Ammonia Assimilation in Trichosporon cutaneum
}

\author{
By B. JOHNSON \\ Department of Microbiology, The University, Newcastle upon Tyne $N E_{\mathrm{I}}{ }_{7} R U$
}

(Received 28 January 1975; revised 28 February 1975)

\section{INTRODUCTION}

Two major routes of ammonia assimilation have been implicated in yeasts. The first involves anabolic (aminating) NADP-linked glutamate dehydrogenase, the highest activities of which are usually observed in growth in environments containing low concentrations of ammonia (Brown \& Johnson, 1970) or where nitrate is the nitrogen source (Burn, Turner $\&$ Brown, 1974). The second is a dual enzyme system comprising glutamine synthetase and glutamate synthase (Brown, Burn \& Johnson, I973; Roon, Even \& Larimore, I974; Johnson \& Brown, 1974), which is believed to be of major significance when ammonia concentrations are low.

The role of NAD-linked glutamate dehydrogenase has been assumed to be primarily a catabolic (deaminating) one, since highest activities of this enzyme are observed during growth on organic nitrogen sources (Polakis \& Bartley, I965; Thomulka \& Moat, 1972; Ferguson \& Sims, 1974).

The present communication reports upon the activities of possible ammonia-assimilating enzymes in Trichosporon cutaneum, grown in batch and continuous cultures.

\section{METHODS}

The organism employed in this study, Trichosporon cutaneum (NCYC444) was maintained at $4{ }^{\circ} \mathrm{C}$ on yeast extract ( $\%$, w/v)-peptone $(2 \%, w / v)$-glucose $(2 \%, w / v)$ agar and subcultured every two months.

Organisms were grown in batch and continuous cultures in media containing: $\mathrm{KH}_{2} \mathrm{PO}_{4}$, $7.35 \times 10^{-3} \mathrm{M} ; \mathrm{MgSO}_{4} \cdot 7 \mathrm{H}_{2} \mathrm{O}, 4.06 \times 10^{-3} \mathrm{M} ; \mathrm{CaCl}_{2} .2 \mathrm{H}_{2} \mathrm{O}, \mathrm{I} \cdot 70 \times 10^{-3} \mathrm{M}$; trisodium citrate. $2 \mathrm{H}_{2} \mathrm{O}, 4.45 \times \mathrm{IO}^{-3} \mathrm{M}$; citric acid. $\mathrm{H}_{2} \mathrm{O}, 3.52 \times \mathrm{IO}^{-3} \mathrm{M} ; \mathrm{ZnSO}_{4} \cdot 7 \mathrm{H}_{2} \mathrm{O}, 3.48 \times 10^{-8} \mathrm{M} ;\left(\mathrm{NH}_{4}\right)_{6}{ }^{-}$ $\mathrm{Mo}_{7} \mathrm{O}_{24} \cdot 4 \mathrm{H}_{2} \mathrm{O}, \mathrm{I} \cdot 62 \times \mathrm{IO}^{-8} \mathrm{M} ; \mathrm{CuSO}_{4} \cdot 5 \mathrm{H}_{2} \mathrm{O}, \mathrm{I} \cdot 80 \times \mathrm{IO}^{-7} \mathrm{M}^{2} \mathrm{FeSO}_{4} \cdot 7 \mathrm{H}_{2} \mathrm{O}, 8.99 \times \mathrm{IO}^{-7} \mathrm{M}$; meso-inositol, $\mathrm{I} \cdot \mathrm{II} \times \mathrm{IO}^{-4} \mathrm{M}$; pyridoxine- $\mathrm{HCl}, 2.43 \times 10^{-6} \mathrm{M}$; calcium pantothenate, $4.20 \times$ $10^{-6} \mathrm{M}$; nicotinic acid, $3.25 \times \mathrm{I}^{-5} \mathrm{M}$; thiamine-HCl, $\mathrm{I} \cdot \mathrm{I} 9 \times 10^{-6} \mathrm{M}$; D-biotin, $4.09 \times 10^{-9} \mathrm{M}$. Glucose and the nitrogen source (either ammonium sulphate or monosodium glutamate) were added as required. The media employed were either 'low nitrogen' $\left[\left(\mathrm{NH}_{4}\right)_{2} \mathrm{SO}_{4}\right.$, $\mathrm{I} \cdot 80 \times \mathrm{IO}^{-3} \mathrm{M}$ or monosodium glutamate, $4.0 \times 1 \mathrm{IO}^{-2} \mathrm{M}$, with glucose, $\left.5.55 \times 1 \mathrm{I}^{-2} \mathrm{M}\right]$ or ' $\mathrm{high}$ nitrogen' $\left[\left(\mathrm{NH}_{4}\right)_{2} \mathrm{SO}_{4}, \mathrm{I} \cdot 5 \mathrm{I} \times \mathrm{IO}^{-2} \mathrm{M}\right.$ or monosodium glutamate, $3.0 \times 10^{-2} \mathrm{M}$, with glucose $\left.\mathrm{I} \cdot \mathrm{II} \times \mathrm{IO}^{-2} \mathrm{M}\right]$. The final $\mathrm{pH}$ of the medium was buffered by the trisodium citrate-citric acid at 4.5 .

Batch cultures were grown in $750 \mathrm{ml}$ portions in 21 capacity flasks at $25^{\circ} \mathrm{C}$, in an orbital shaker incubator (A. Gallenkamp \& Co. Ltd, Stockton-on-Tees, Teesside) using the 'low nitrogen' medium. Chemostat cultures were grown in a 0.51 capacity vessel of the type described by Brown \& Rose (I969) at $25{ }^{\circ} \mathrm{C}$, employing a dilution rate of $0.05 \mathrm{~h}^{-1}$. Batch cultures were harvested in the late exponential phase of growth, and chemostat cultures directly from the culture vessel. 
Table I. Influence of the nature and concentration of medium nitrogen source on the activities of ammonia assimilating enzymes in chemostat cultures of $T$. cutaneum

\begin{tabular}{|c|c|c|c|c|c|}
\hline \multirow[b]{3}{*}{ Cultural condition* } & \multicolumn{5}{|c|}{ Enzyme activity (nmol/min/mg protein) } \\
\hline & \multirow{2}{*}{$\begin{array}{l}\text { Glutamine } \\
\text { synthetase }\end{array}$} & \multicolumn{2}{|c|}{ Glutamate synthase } & \multicolumn{2}{|c|}{ Glutamate dehydrogenase } \\
\hline & & NAD & NADP & NAD & NADP \\
\hline Ammonia limitation & $10 \cdot 8$ & $8 \cdot 8$ & ND & I $3 I-8$ & ND \\
\hline Ammonia excess & 6.0 & $8 \cdot 0$ & ND & $307 \cdot 3$ & ND \\
\hline Glutamate limitation & $45 \cdot 7$ & 10.5 & ND & $262 \cdot 4$ & ND \\
\hline Glutamate excess & $32 \cdot 4$ & I $2 \cdot I$ & ND & $256 \cdot 7$ & ND \\
\hline
\end{tabular}

$\mathrm{ND}$, Not detectable (i.e. less than $0.5 \mathrm{nmol} / \mathrm{min} / \mathrm{mg}$ protein) although assayed at both $\mathrm{pH} 6 \cdot 5$ and 7.5 .

* For composition of media, see Methods.

Enzyme extracts were prepared as described by Brown \& Johnson (I970) using 100 mMphosphate buffer $\mathrm{pH} 7{ }^{\circ} \mathrm{O}$. The activities of NADP- and NAD-linked glutamate dehydrogenase, NADP- and NAD-linked glutamate synthase and glutamine synthetase were assayed as described by Johnson \& Brown (1974). NADP- and NAD-linked alanine dehydrogenase was assayed by the method used for glutamate dehydrogenase, except that pyruvate was substituted for 2-oxoglutarate. The protein contents of the extracts were determined by the method of Lowry et al. (195I).

\section{RESULTS AND DISCUSSION}

Extracts prepared from ammonia-grown batch cultures were initially assayed in a $\mathrm{pH}$ range of 5.8 to $9 \cdot 2$ for the enzymes described under Methods. NADP-linked glutamate dehydrogenase was not detectable, and no alanine dehydrogenase activity, either NAD- or NADP-linked, was found. The organism did contain NAD-linked glutamate dehydrogenase activity (pH optimum 8.3), NAD-linked glutamate synthase activity (pH optimum $7 \cdot 6$ ) and glutamine synthetase activity (pH optimum 6.5).

The apparent absence of NADP-linked glutamate dehydrogenase in this organism was rather surprising, since in most yeasts studied to date it is present (Burn et al. 1974); this prompted a closer examination of the activities of ammonia-assimilating enzymes when $T$. cutaneum was grown under different conditions. Chemostat cultures were established and the organisms grown under conditions of ammonia limitation, ammonia excess (glucose limited), glutamate limitation and glutamate excess (glucose limited). The activities of NADlinked glutamate dehydrogenase, NAD-linked glutamate synthase and glutamine synthetase were assayed at their $\mathrm{pH}$ optima (see above). NADP-linked glutamate dehydrogenase, NADP-linked glutamate synthase, and NAD- and NADP-linked alanine dehydrogenase were assayed at $\mathrm{pH} 6 \cdot 5$ and $7 \cdot 5$.

The results of these experiments are shown in Table $\mathrm{I}$. The only enzymes detectable were those which had been present in batch cultures. Glutamine synthetase activity was found under all conditions tested, although at a markedly higher level in the presence of glutamate. This finding differs from results obtained previously with Schizosaccharomyces sp. and Saccharomycodes ludwigii (Johnson \& Brown, 1974), but agrees with results obtained in studies involving Candida utilis by Ferguson \& Sims (1974). NAD-linked glutamate dehydrogenase was detectable in substantial quantities under all conditions, although its level was somewhat reduced at limiting concentrations of ammonia. Previous studies (Hierholzer \& Holzer, 1963; Westphal \& Holzer, 1964; Thomulka \& Moat, 1972; Burn et al. 1974; 
Ferguson \& Sims, 1974), involving a variety of yeasts, have indicated that the presence of glutamate in the growth medium normally increases the level of NAD-linked glutamate dehydrogenase. Trichosporon cutaneum is unusual in that even in the absence of glutamate, the level of the enzyme remains high. NAD-linked glutamate synthase activity was present at a consistently low level, similar to results obtained previously with different organisms (Brown et al. 1973; Roon et al. 1974; Johnson \& Brown, 1974). In the present case, the possibility that the observed activity may have been due to the combined activity of a glutaminase and NAD-linked glutamate dehydrogenase cannot be totally precluded.

Thus, so far as nitrogen assimilation is concerned, T. cutaneum appears to differ from the majority of yeasts examined in two ways: NADP-linked glutamate dehydrogenase is absent, and NAD-linked glutamate dehydrogenase is present at a consistently high level. It is therefore possible that the latter enzyme plays both an anabolic and catabolic role in this organism, rather than the solely catabolic role which it is presumed to have in organisms possessing the NADP-linked enzyme. When assayed in crude extracts at pH 8.3, NADlinked glutamate dehydrogenase from $T$. cutaneum showed $K_{m}$ values for ammonia of $\mathrm{I} \cdot 33 \times 10^{-2} \mathrm{M}$, for 2-oxoglutarate of $8.0 \times 10^{-4} \mathrm{M}$, for NADH of $2.4 \times 10^{-5} \mathrm{M}$, for L-glutamate of $2.0 \times 10^{-3} \mathrm{M}$, and for NAD of $4.8 \times \mathrm{IO}^{-4} \mathrm{M}$. These values, particularly that for ammonia, are of the same order as those previously reported for the enzyme in Saccharomyces cerevisiae (Holzer \& Schneider, 1957) and in other fungi (Sanwal, 196I; Sanwal \& Lata, 196I). Thus, the enzyme from $T$. cutaneum does not show an unusually high affinity for ammonia, but if the enzyme does function anabolically this may be compensated for by its continued synthesis at a high level in the presence of ammonia. Such 'compensatory synthesis' is believed to operate in the case of NADP-linked glutamate dehydrogenase in many yeasts (Brown et al. 1973).

It is tempting, although perhaps premature, to speculate that the apparently constitutive synthesis of NAD-linked glutamate dehydrogenase may reffect the 'natural' habitat of this organism, which is frequently found in association with warm-blooded animals (Do CarmoSousa, 1970). Under such conditions, the predominant available nitrogen sources would probably be organic, and it is possible that the ability of $T$. cutaneum to utilize ammonia efficiently represents an evolutionary modification of those mechanisms controlling the synthesis of NAD-linked glutamate dehydrogenase.

\section{REFERENCES}

Brown, C. M., Burn, V. J. \& Johnson, B. (1973). Presence of glutamate synthase in fission yeasts, and its possible role in ammonia assimilation. Nature New Biology 246, 1 i 5-1 16.

Brown, C. M. \& Johnson, B. (1970). Influence of the concentration of glucose and galactose on the physiology of Saccharomyces cerevisiae in continuous culture. Journal of General Microbiology 64, 279-289.

Brown, C. M. \& Rose, A. H. (1969). Effects of temperature on composition and cell volume of Candida utilis. Journal of Bacteriology 97, 26I-272.

Burn, V. J., Turner, P. R. \& Brown, C. M. (1974). Aspects of inorganic nitrogen assimilation in yeasts. Antonie van Leeuwenhoek 40, 93-102.

Do Carmo-Sousa, L. (1970). Genus I I: Trichosporon. In The Yeasts. A Taxonomic Study, pp. 1323-1326. Edited by J. Lodder. Amsterdam and London: North Holland.

Ferguson, A. R. \& Sims, A. P. (1974). The regulation of glutamine metabolism in Candida utilis: the role of glutamine in the control of glutamine synthetase. Journal of General Microbiology 80, I 59-171.

Hierholzer, G. \& Holzer, H. (1963). Repression der Synthese von DPN-abhängiger Glutaminsäuredehydrogenase in Saccharomyces cerevisiae durch Ammoniumionen. Biochemische Zeitschrift 339, $175-185$.

Holzer, H. \& Schneider, S. (1957). Anreicherung und Trennung einer DPN-spezifischen und einer TPN spezifischen Glutaminsäure-Dehydrogenase aus Hefe. Biochemische Zeitschrift 329, 36I-369. 
Johnson, B. \& Brown, C. M. (1974). The enzymes of ammonia assimilation in Schizosaccharomyces sp. and in Saccharomycodes ludwigii. Journal of General Microbiology 85, 169-172.

Lowry, O. H., Rosebrough, N. J., Farr, A. L. \& Randall, R. J. (I95I). Protein measurement with the Folin phenol reagent. Journal of Biological Chemistry 193, 265-275.

Polakis, E. S. \& Bartley, W. (1965). Changes in enzyme activities or Saccharomyces cerevisiae during aerobic growth on different carbon sources. Biochemical Journal 97, 284-297.

RoON, R. J., Even, H. L. \& LARIMORE, F. (1974). Glutamate synthase: properties of the reduced nicotinamide adenine dinucleotide-dependent enzyme from Saccharomyces cerevisiae. Journal o Bacteriology 118, 89-95.

Sanwal, B. (196I). Diphosphopyridine nucleotide and triphosphopyridine nucleotide linked glutamic dehydrogenases of Fusarium. Archives of Biochemistry and Biophysics 93, 377-386.

Sanwal, B. \& LATA, M. (I96I). The occurrence of two distinct glutamic dehydrogenases in Neurospora. Canadian Journal of Microbiology 7, 319-328.

Thомulka, K. W. \& MoAT, A. G. (1972). Inorganic nitrogen assimilation in yeasts: alteration in enzyme activities associated with changes in cultural conditions and the growth rate. Journal of Bacteriology ro9, 25-33.

WestPHAL, W. \& Holzer, H. (1964). Synthese von NAD-abhängiger Glutamatdehydrogenase in Protoplasten von Saccharomyces carlsbergensis. Biochimica et biophysica acta 89, 42-46. 